\title{
GRAVITY IMAGING AT NORTHERN PARANÁ BASIN: AIRBORNE GRAVITY DATA ANALYSIS AND FORWARD MODELING SIMULATIONS
}

\author{
Alan de Souza Cunha ${ }^{1,2}$, Leandro Barros Adriano ${ }^{1}$, Fábio André Perosi ${ }^{2}$, Marlon Hidalgo-Gato Cabrera', \\ Manuela da Silva Adriano ${ }^{3}$, Emanuele Francesco La Terra ${ }^{3}$, Sergio Luis Fontes ${ }^{3}$ and Daniel Santos Silva ${ }^{1}$
}

\begin{abstract}
The geophysical imaging of sub-basalt targets is still the main objective of the current exploratory efforts at Paraná Basin, Brazil. The Serra Geral Formation represents a singular challenge in world's geology that consists in performing geophysical investigation under a thick basalt layer. Through the forward modeling of standard reference models, supported by the idea to simulate the gravity response of the basin in a virtual environment, it was possible to understand the contribution of each geologic feature to the overall gravity content. By applying the proposed methodology, we investigated which features can be assuredly interpreted with the current gravity dataset available in the area of study, which corrections and filters are better to enhance sub-basalt targets, and finally, if the removal of the gravity response from Serra Geral model improves the imaging of these anomalies. The several simulations indicated that a simple application of the classical gravity corrections and conventional filtering are not efficient to mapping the spatial distribution of igneous intrusive rocks with similar dimensions of Barra Bonita field. Supported by a 2D modeling of the gravity survey, the 3D simulation also indicated the need to improve the Serra Geral density and geometric model before going forward with any geophysical investigation that involves the density as key property.
\end{abstract}

Keywords: 3D simulation, complex synthetic model, sub-basalt targets.

RESUMO. 0 imageamento de prospectos sub-basalto ainda é o principal objetivo dos projetos exploratórios na Bacia do Paraná, Brasil. A Formação Serra Geral representa um desafio singular da geologia global que consiste em executar a investigação geofísica abaixo de uma espessa camada de basaltos. Através de modelagem direta de modelos consagrados da bacia, embasada pela ideia de simular a resposta gravimétrica da bacia em um ambiente virtual, foi possível entender a contribuição de cada feição geológica para composição da resposta gravimétrica completa da bacia. Com a aplicação da metodologia proposta, investigamos quais feições geológicas podem ser interpretadas utilizando o dado gravimétrico disponível na área de estudo, quais correções e filtros são melhores para realçar anomalias sub-basalto e, finalmente, se a remoção do efeito gravimétrico do modelo do Serra Geral facilitaria o mapeamento dessas anomalias. As diversas simulações indicaram que a simples aplicação das correções gravimétricas clássicas e filtragens convencionais não são eficientes no mapeamento da ocorrência de ígneas intrusivas de dimensões análogas ao campo de Barra Bonita. Baseada em uma modelagem 2D do dado gravimétrico real, a simulação 3D também evidenciou a necessidade de melhoria do modelo geométrico e de densidades da Formação Serra Geral antes de seguir com qualquer outra investigação geofísica que envolva densidade como propriedade física fundamental.

Palavras-chave: simulação 3D, modelo sintético complexo, prospectos sub-basalto.

\footnotetext{
1CCG - CGG Brazil, Rio de Janeiro, RJ, Brazil - E-mails: alan.cunha@cgg.com; leandro.adriano@cgg.com; marlon.cabreira@cgg.com; daniel.silva2@cgg.com

2 Universidade Federal do Rio de Janeiro - UFRJ, Instituto de Geociências, Departamento de Geologia, Laboratório de Geofísica e Petrofísica - LAGEP, Rio de Janeiro, RJ, Brazil - E-mail: faperosi@geologia.ufrj.br

30bservatório Nacional - 0N, Rio de Janeiro, RJ, Brazil - E-mails: manuela_rj@yahoo.com.br; laterra@on.br; sergio@on.br
} 


\section{INTRODUCTION}

Paraná Basin is the largest onshore Brazilian basin, situated in the central-southern of Brazil being crossed by the Paraná River compromising partially seven adjoining states (Fig. 1).

Paraná Basin extends, in Brazilian territory, 1,100,000 square kilometers of sedimentary and igneous rocks. About $70 \%$ of its surface is covered by basalt floods. From the geological standpoint and geophysical approach, it remains one of the most challenging Brazilian's basin regarding the subsurface imaging and sedimentary correlation.

Even after a strong exploration effort made by companies leading newly geophysical and geological data acquisition over the $0 \& G$ conceded areas, seismic imaging is still poor and the available potential field data presents strong limitations to interpret any element related to the petroleum system inside the basin.

The evolution of the knowledge about the basin is tied to image geologic features below the thick layer of basalt of the Serra Geral Formation. Due to its physical properties and the nature of the gravity response, the Serra Geral Formation can be responsible of hindering the gravity signal from the underlying layers, masking smaller density contrasts and impeding to segregate a clear frequency content from interest targets, including intrusive rocks and basement.

Considering this lack of knowledge and the availability of classical models for the basement (Quintas, 1995; Quintas et al., 1997) and Serra Geral Geometry (Quintas et al., 1997), Digital Terrain model (Farr et al., 2007); and a Moho model - Crust 1.0 (Laske et al., 2013), we build a 3D model, simulating the gravity response from a virtual Paraná Basin to exercise the imaging problems.

The importance of the complex forward simulations in Geophysics is increasing simultaneously with the development of the computer capacity of processing and visualizing complex data. Simulations are very common in geoscience, especially for reservoir studies, debris flow modeling or any dynamic analysis of the certain natural element in a specific system. In the other hand, synthetic modeling is in the classic workflow for testing the main geophysical interpretation tools: filters and inversion algorithms, but the model here developed is much more complex than classical synthetic modeling and do not simulate any dynamic element. The idea is to introduce the concept of basin response simulation using reliable models and understand the missing elements to fit the modeled response to real data. Another objective is to investigate the technical problems to detect and model igneous intrusive rocks using the current gravity dataset available over the basin. For that, we combined the forward gravity response of the standard reference models that represents the main geologic features with considerable impact in the gravity field, such as Moho surface, Basement, Igneous intrusive and extrusive rocks and Terrain model to compare with real data available in the area of study.

\section{Geological Summary}

The studied area is located in the central-south region of the Tocantins Structural Province (Fig. 2). The basin has a NNE-SSWtrending elliptical shape with two-thirds of its surface covered by Mesozoic basaltic lavas (Hasui, 2010). The stratigraphic record of the basin exceeds 7,000 $\mathrm{m}$ in thickness in the central depocenter, just below the river that lends its name to the basin (Milani et al., 2007).

The basement of the Paraná Basin is characterized by complex structure of crustal elements consolidated by tectono-magmatic phenomena of the Brazilian Cycle, in the interval NeoproterozoicEopaleozoic (Hasui et al., 2012 apud Almeida, 1980; Zalán et al., 1990; Milani, 1997), this complex structure, composed by an extensive cratonic core named Paranapanema Craton and the Transbrasiliano Lineament (Hasui et al., 2012 apud Cordani, 2008) or with different smaller cratonic blocks interleaved by fold belts proposed by Milani \& Ramos (1998), may reflects in the gravity measurements.

Mariani et al. (2013) describe the basin filling through the following events: During Paleozoic the basin formed in alternating marine and continental environment, forming the pre-volcanic sequence (Gama \& Bandeira, 1982; Piccirillo \& Melfi, 1988). Starting in Early Cretaceous, intense volcanic activity formed the Serra Geral Formation, mainly composed of tholeiitic basalts and rare rhyodacytes and rhyolites <3\%; (Piccirillo et al., 1987). Due to its large dimensions the Serra Geral Formation is classified as a Large Igneous Province (Bryan \& Ernst, 2008). In the Late Cretaceous the northern part of the basin subsided and the postvolcanic rocks of the Bauru Group were deposited (Fig. 3). The post-basalt cover constitutes a psamtik siliciclastic unit accumulated in semiarid to desert conditions. The Bauru Supersequence has discordant basal contact, mainly with basalts from the Serra Geral Formation (Milani et al., 1994).

The Serra Geral Formation represents one of the major manifestations of episodic volcanism of the Neocomian. Among the subaerial Large Igneous Provinces of the world, the Cretaceous Paraná-Etendeka Continental Flood Basalt Province (CFBP) ranks as second largest, surpassed only by the Siberian Traps in the Tunguska Basin (Frank et al., 2009).

Serra Geral Formation records a maximum thickness of up to 2,000 meters over the sediments of the Paraná Basin, mainly 


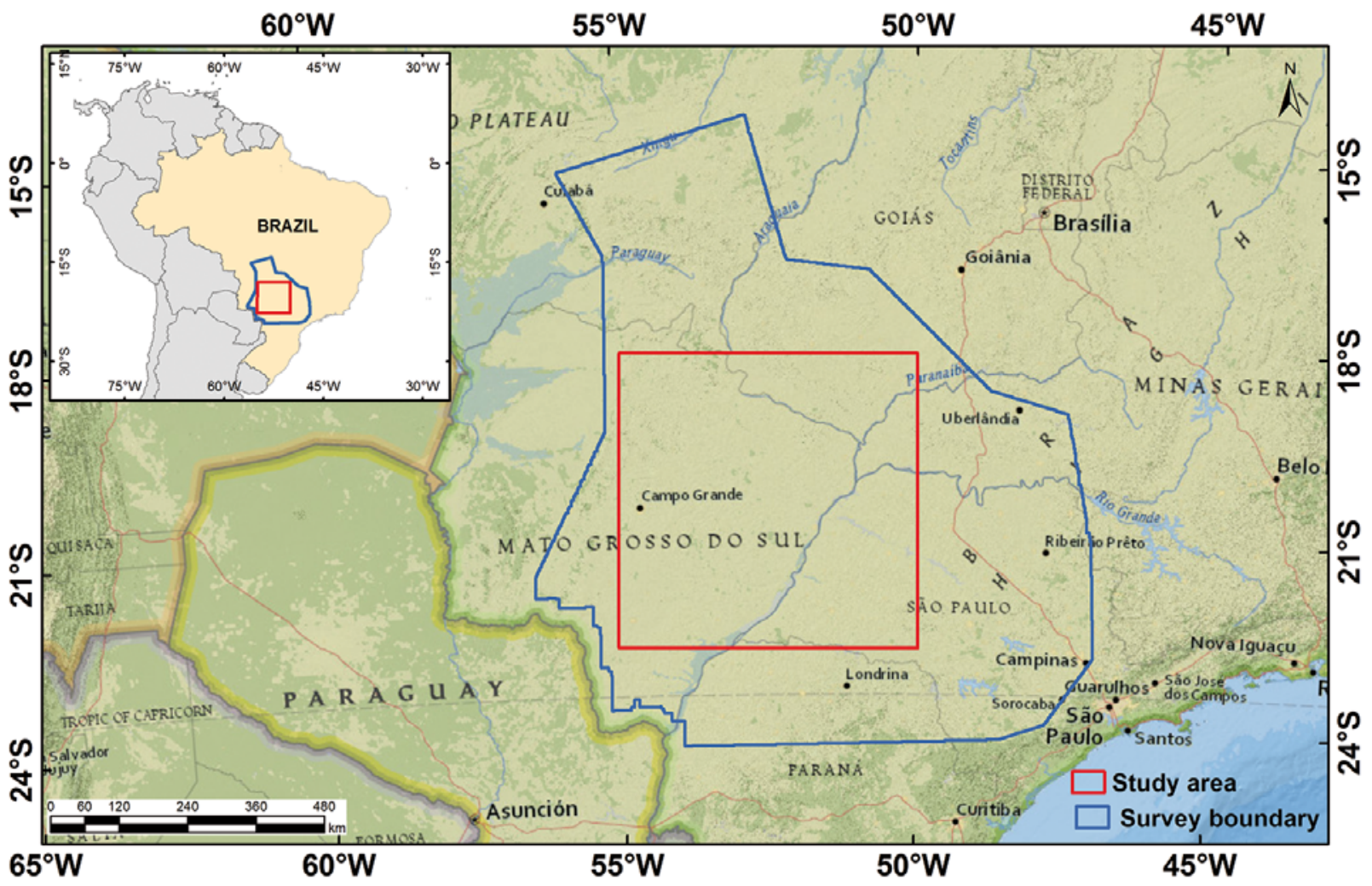

Figure 1 - Location map of the survey area (blue polygon) and the model area (red square).

(a)

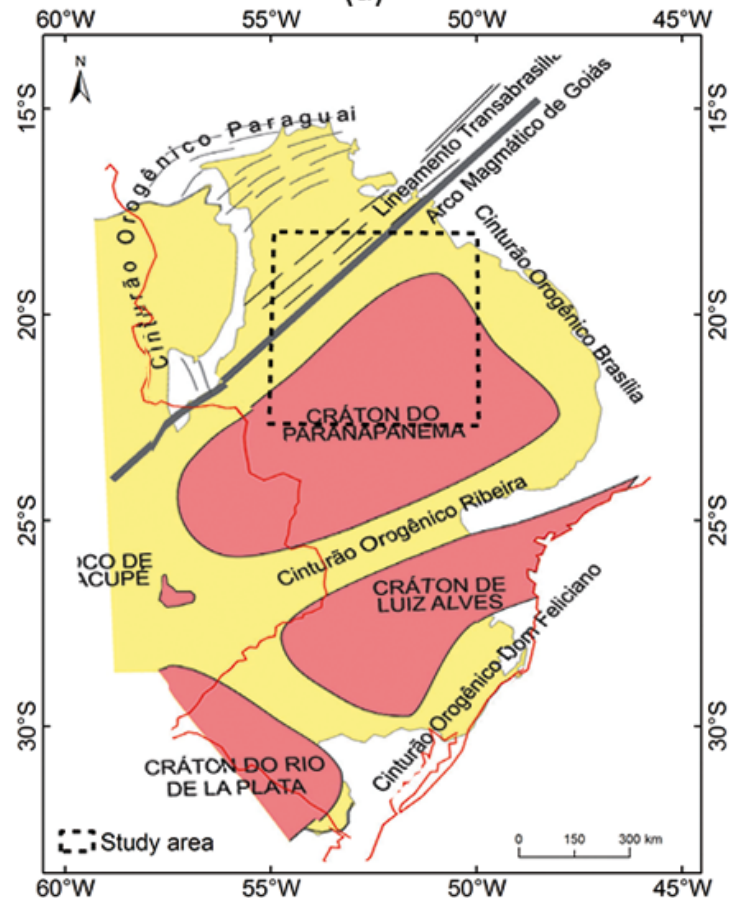

(b)

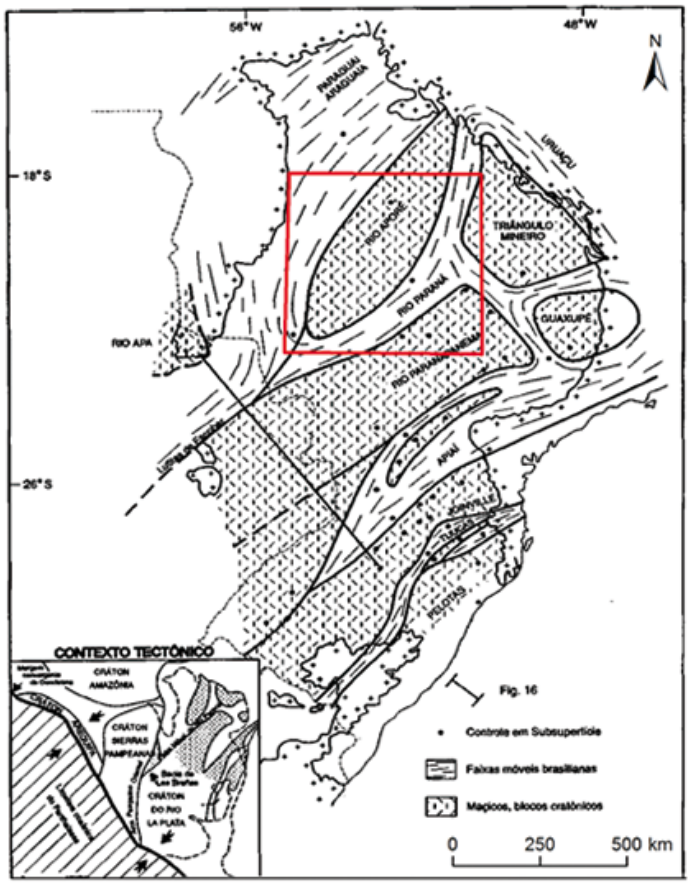

Figure 2 - Basement compartments with the location of the study area: (a) Hasui et al., 2012 apud Cordani (2008); (b) Milani \& Ramos (1998). Modified from Hasui (2012). Modified from Milani \& Ramos (1998). 


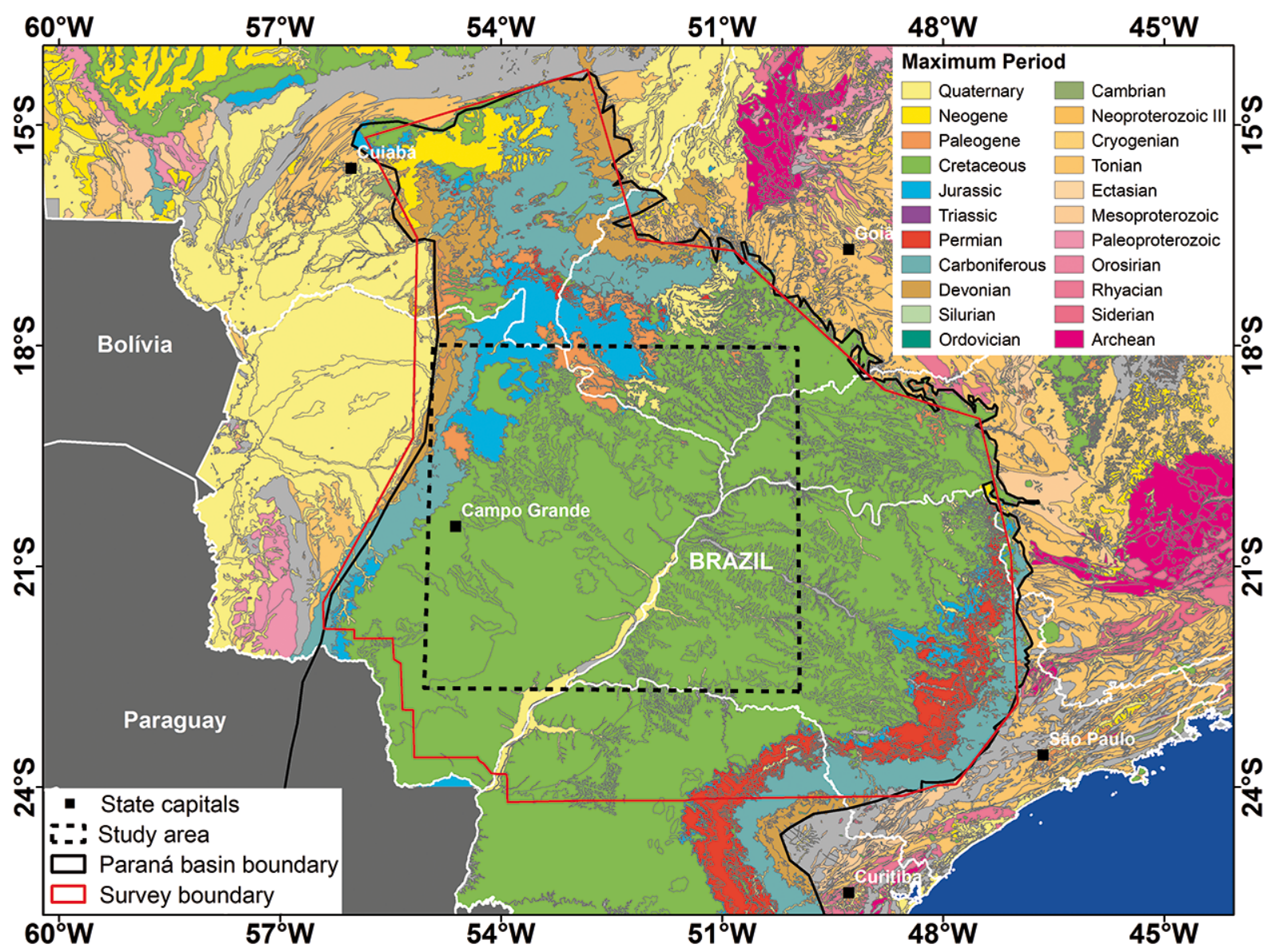

Figure 3 - Geologic map and Paraná Basin boundary - Source: CPRM (2004).

represented by volcanism of basic nature and some subordinated acid rocks. There was also an important intrusive activity represented by sills and dikes associated. The basalts present a concordant and abrupt contact with the undertake eolic sandstones from the Botucatu Formation. It is common, in the most basal portions of the volcanic sequence, the presence of sandstone intertraps among the lava spills (Reis et al., 2014). Observing that Serra Geral Formation presents bigger density if compared to the underlying layers and is the shallower formation in most of the area of the Paraná Basin, the gravity mapping of the underlying geologic features can be challenging.

\section{Geophysical Dataset - Airborne Gravimetric Survey}

The geophysical dataset herein used was acquired by the Brazilian National Agency of Petroleum, Natural Gas and Biofuels (ANP) in 2010 with a survey code ANP_03032_Paraná_GRAV and is composed by 173,937.0 linear kilometers of airborne gravity profiles presenting 6,000 meters of line spacing in flight lines (N-S trend) and 18,000 meters line spacing of control lines
(E-W trend) covering approximately $730,000 \mathrm{~km}^{2}$. The airborne gravity meters used in this survey were GT1-A (Resolution: $0.2 \mathrm{mGal}$ ) and Graviton (Resolution: $0.1 \mathrm{mGal}$ ) Systems. The nominal flight height was 1,800 meters above the sea level and the ground clearance varied from 549 to $1,705 \mathrm{~m}$, with a mean clearance of 1,294 $\mathrm{m}$ and a standard deviation of $170 \mathrm{~m}$. The acquisition sampling was 15 meters. This survey covers the Brazilian states of Minas Gerais, São Paulo, Mato Grosso, Paraná and Santa Catarina (Fig. 1).

Figure 4 shows the classical Free-Air Anomaly and Bouguer Anomaly Maps, they represent the basic products from the airborne gravity survey.

\section{Methodology}

The applied methodology consists in compute a 3D gravity model of the main elements that compose the basin architecture using structural tops maps (Quintas et al., 1997), Terrain model (Farr et al., 2007) and Moho surface model - Crust 1.0 (Laske et al., 2013). The Figure 5(a) shows the Terrain model, the Figure 5(c) 

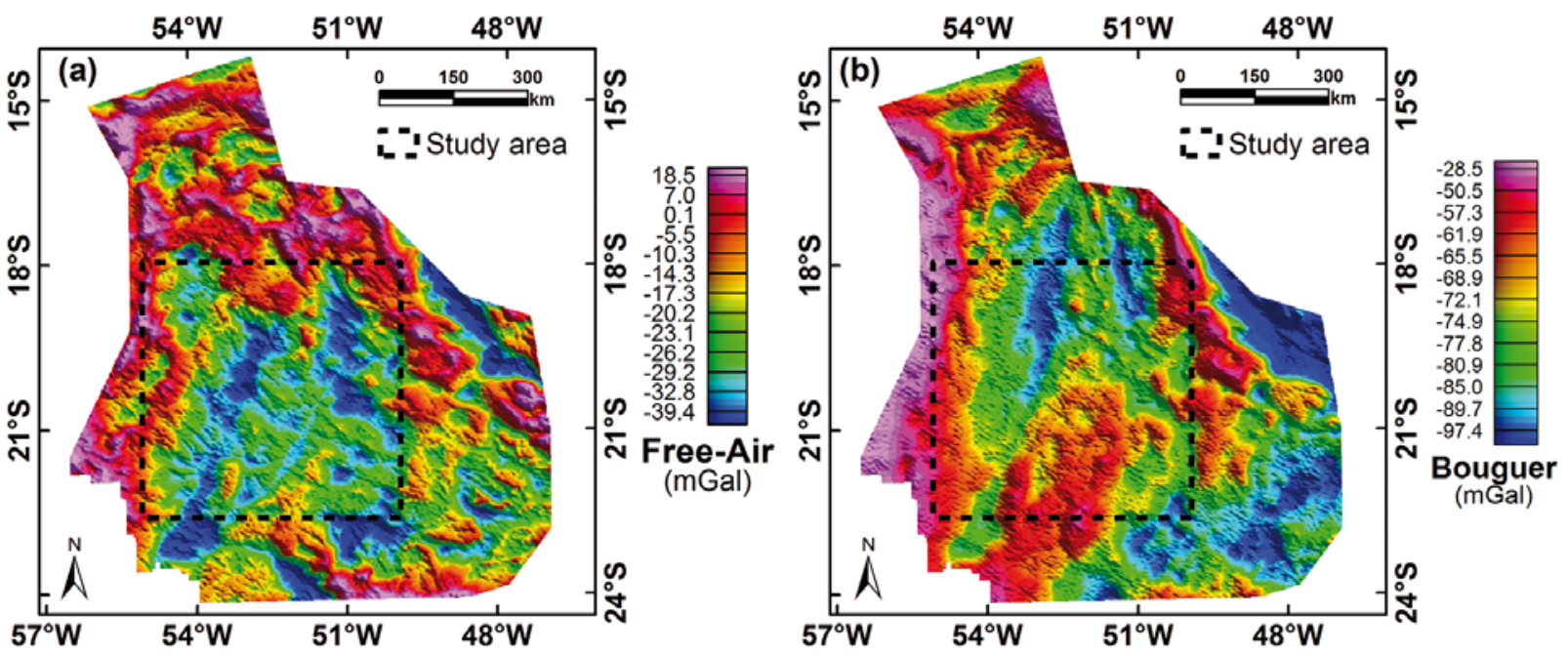

Figure 4 - (a) Aerogravimetric Free-Air Anomaly map; (b) Aerogravimetric Bouguer Anomaly map (Density $2.67 \times 103$ kg/m³).

(a) TERRAIN MODEL

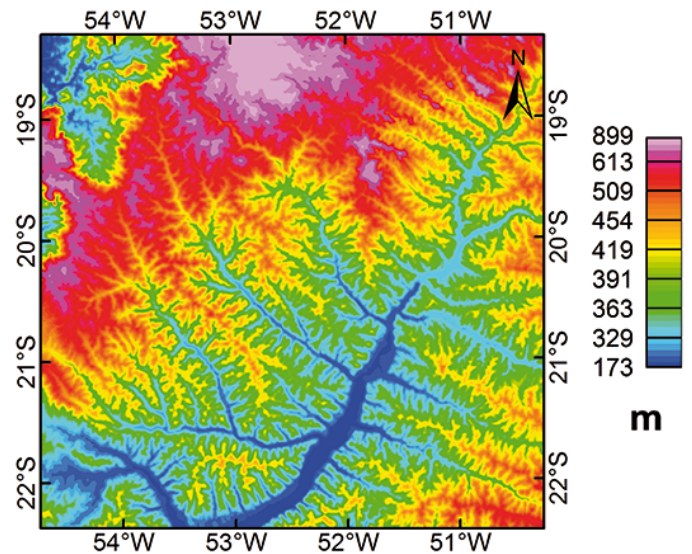

(c) BASALT'S BOTTOM MODEL

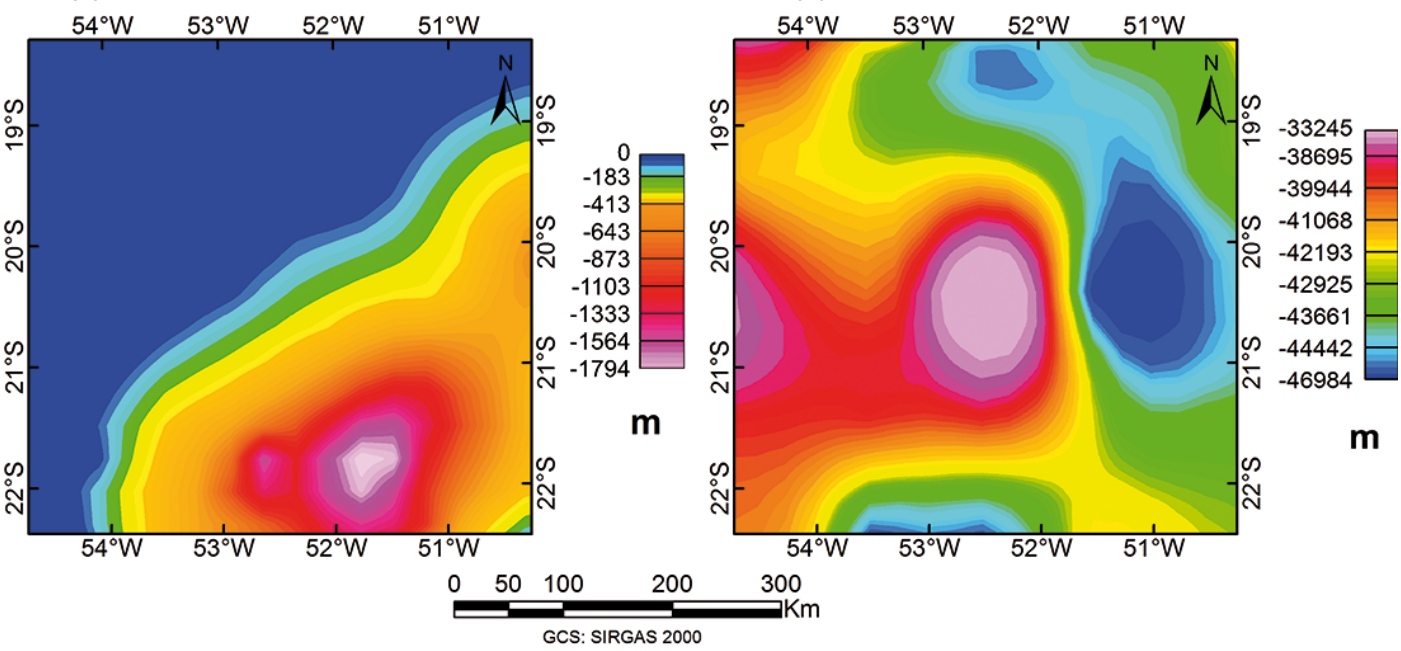

Figure 5 - Structural top mpas from the modeled geologic features to compose the final basin model: (a) Digital Terrain Model (Farr et al., 2007); (b) Basement model (Quintas et al., 1997); (c) Serra Geral Model (Quintas et al., 1997); (d) Moho model - Crust 1.0 (Laske et al., 2013). (b) BASEMENT MODEL

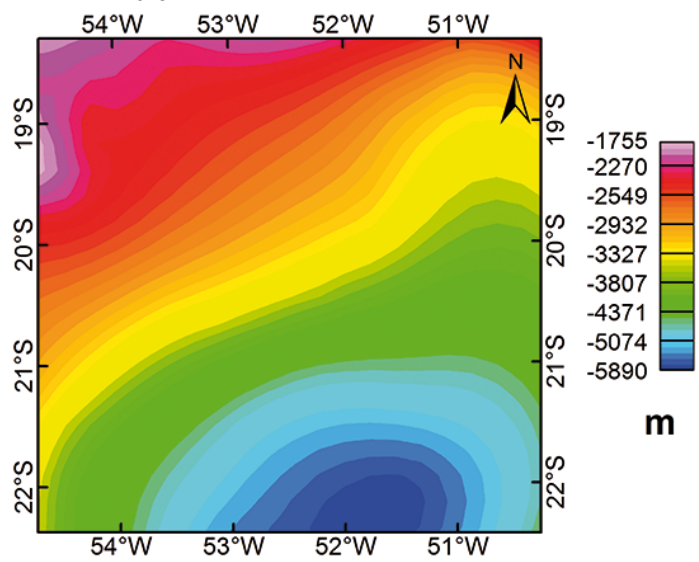

(d) MOHO SURFACE MODEL

m 
shows the Basalt Bottom map (Quintas et al., 1997) and, finally, the Figures 5(b) and 5(d) show the basement model (Quintas et al., 1997) and Moho surface model (Laske et al., 2013), respectively. These surfaces were used to calculate the gravity field for an specific density contrast (Fig. 6), that stacked, simulate the overall gravity vertical field (Fig. 8b\&c) of the known geologic features of the basin. The 3D model was built in Python language, using prisms models (Blakely, 1995), with the support of the open-source software "Fatiando a Terra" (Uieda et al., 2013). The classical corrections, such as terrain and isostatic corrections were applied also using those models, through a simple subtraction grid operation to remove the terrain gravity response and the Moho model gravity response, respectively. In order to simplify the gravity field computation we limited our model to the center of the northern part of the basin (Fig. 1 - red square).

For simulation purposes, some modeled features were generated with no constrain, to complement the lack of information of known geologic features inside the basin. As the location of the intrusive igneous rocks is still unknown around the basin, we propose a model using 100 plates with similar dimensions $(3 \mathrm{~km}$ $\times 5 \mathrm{~km}$ in area) of Mato Rico and Barra Bonita structures (Catto, 2008; Cardoso, 2015), randomly distributed in area and depth, from $1,700 \mathrm{~m}$ to $3,900 \mathrm{~m}$, however it is known that these igneous intrusive rocks occur more intensively in Irati Formation and secondarily in Itarare Formation. To better represent a real gravity signal, we also included an arbitrarily noise of $0.2 \mathrm{mGal}$ to the whole model. Figure 6 shows the model and the density contrasts applied to build the model.

Another simplification was not considering any density contrast inside sedimentary sequences, assuming $2.4 \times 10^{3} \mathrm{~kg} / \mathrm{m}^{3}$ for the sedimentary section (Mariani et al., 2013) as an average density for the Paleozoic sediments. The objective of this modeling is to evaluate the capacity of imaging subsurface geology, especially intrusive rock anomalies, after classical corrections and enhancements applied to the gravity data (Fig. 7) in three different scenarios:

- Scenario one - Real Data - Classical corrections and enhancements applied to the real data;

- Scenario two - Forward Model - Corrections and enhancements assuming a constant density to calculate the vertical gravity field of basalts from Serra Geral Formation;

- Scenario three - Forward Model - Corrections and enhancements assuming some arbitrary density variation, from $2.75 \mathrm{~g} / \mathrm{cm}^{3}$ to $2.85 \mathrm{~g} / \mathrm{cm}^{3}$ (Mariani etal., 2013) inside the basalts from Serra Geral Formation.

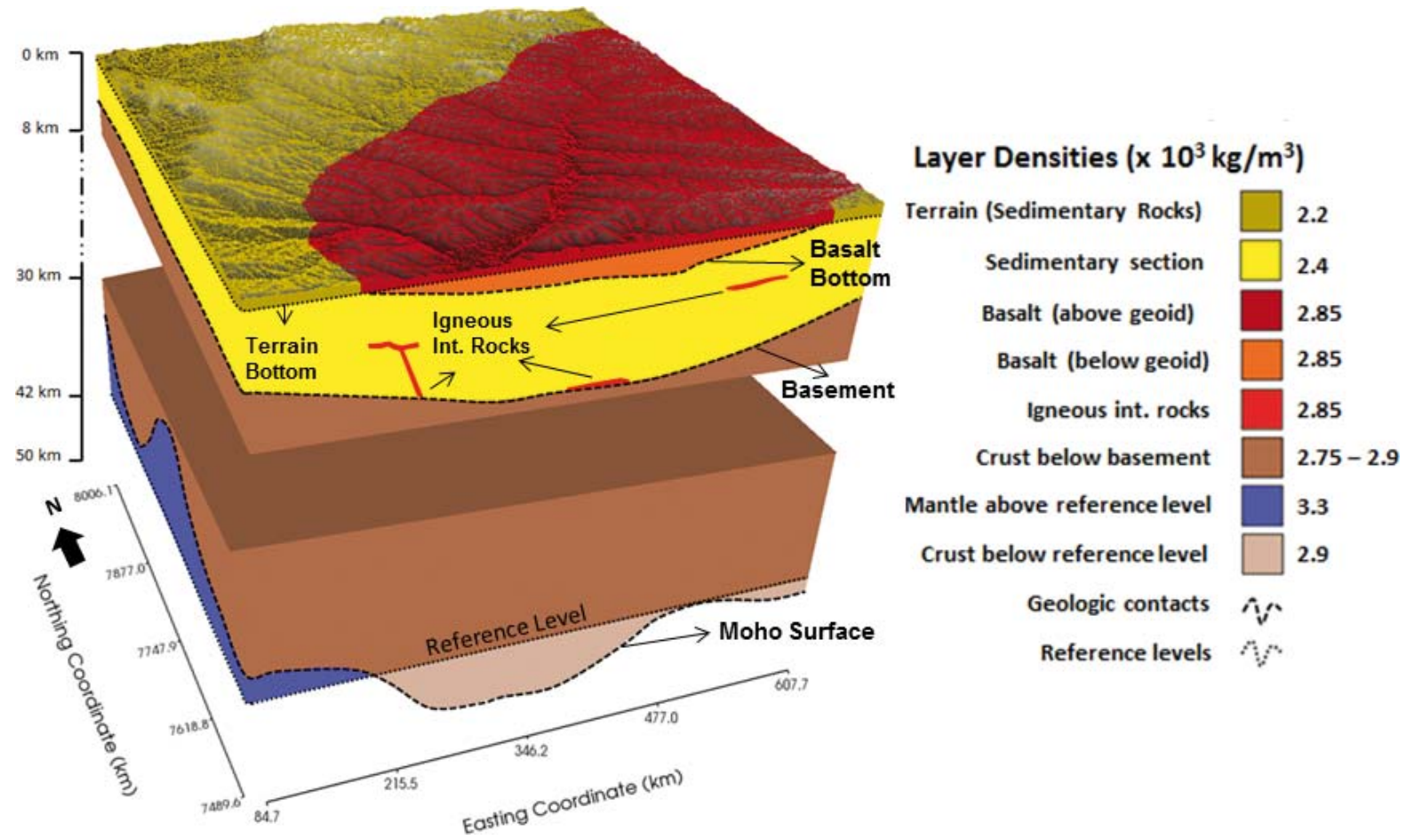

Figure $\mathbf{6}$ - 3D representation of the main interfaces and layers stacked in the model. 


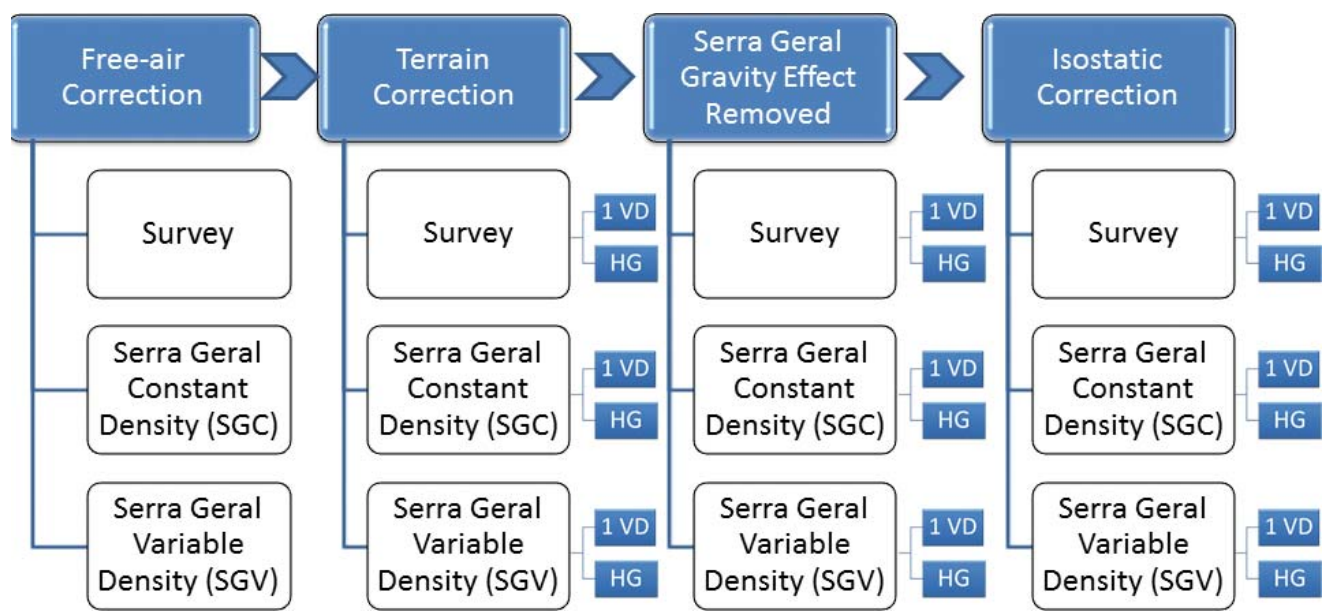

Figure 7 - Workflow to generate and organize the different corrections and filters to be analyzed. 1VD and HG represent the application of the first Vertical Derivative and Horizontal Gradient filters.

The classical Bouguer data of the Paraná Basin, with terrain correction of $2.67 \times 10^{3} \mathrm{~kg} / \mathrm{m}^{3}$, presents a low frequency positive anomaly running along the central axis of the basin (Zálan et al., 1990). To explain this anomaly, Zálan et al. (1990) proposed an area of crustal thinning where subsidence was maximum. It is important to draw attention that, in this area, the outcropping basalts reach a depth close to 2000 meters and the Basalt Model (Quintas et al., 1997) presents the highest thickness. In this sense, would be a good exercise if the gravity response of the basalt could be removed, creating a better window to look directly down at the basement or any other underlying geologic features, and also evaluating if this low frequency positive anomaly in the terrain corrected data, can be explained by the gravity response of the remaining basalt bellow the geoid. Following this idea, we propose one more step of correction that includes, further than terrain correction using $2.20 \times 10^{3} \mathrm{~kg} / \mathrm{m}^{3}$ (Mariani et al., 2013), the removal of the forward gravity effect of the whole Basalt model (Quintas et al., 1997), including the portion below geoid, applying a density contrast of $0.65 \times 10^{3} \mathrm{~kg} / \mathrm{m}^{3}\left(2.85 \times 10^{3} \mathrm{~kg} / \mathrm{m}^{3}\right.$ less $2.20 \times 103 \mathrm{~kg} / \mathrm{m}^{3}$ ) to the interfaces between the basalt model and Bauru Group and Botucatu Formation. We named the result of this procedure as strip residual.

\section{RESULTS}

The Figure 7 presents the workflow to generate the maps. Figure 8 shows the Free-air correction applied to the survey data and the forward gravity vertical field simulating the virtual Paraná Basin. Figure 9 shows the same maps with the location of the synthetic igneous bodies and Figures 8 to 21 show the results of the classical corrections applied to conventional gravity studies, including one more step, the removal of the gravity effect of the Basalt model (strip residual). We also applied some enhancements in order to improve the high frequency sources. To make easy the comparison, all the maps from Figures 8-21 are presented in the same scale.

Figures 8 and 9, Free-air correction maps reflects mostly the topography oriented along northeast trend and, as expected, there is no anomalies related to the igneous intrusive rocks. Figures 10 and 11, show the results of the terrain correction. The extensive high located in the central-southern portion of the map over the basin central axis is evident as per the northeast trend in the Figure 10(a). Figures 10(b) and 10(c) show clear anomalies related to the synthetic igneous bodies spread along the southern and extreme northwestern portions of the map, despite of the fact there are many synthetic bodies in other portions (Fig. 11b and c). Figure 12(a) shows the first derivative filter applied over the terrain corrected map. This basically delineates the limits of occurrence of surface igneous rocks, while Figures 12(b) and 12(c) mark the same anomalies from Figure 11(b) and (c), with a considerable noise content added. Figure 13(a) delimits the borders of high, evident in Figure 10(a), and also enhances some anomalies I0cated in the northwestern portion of the map. Figures 13(b) and 14(c) are very noisy. Figure 14 presents the results of the newly proposed step of correction that removes from survey data the Serra Geral gravity response model. This step converted the widespread high exposed in the Figure 10(a), in an extensive low located over the central axis of the basin (Fig. 14a). Figures 14(b) and 14(c) show almost the same small anomalies related to synthetic igneous bodies from Figure 10(b) and 10(c), 
(a)

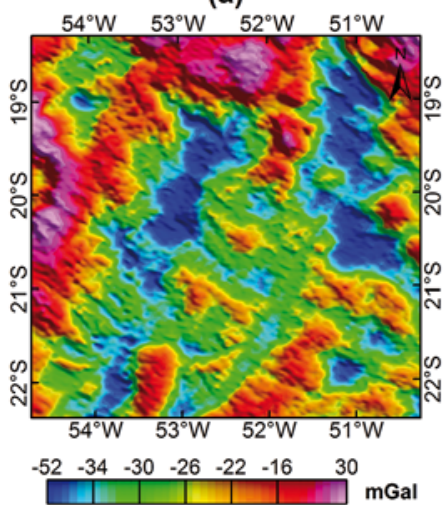

(b)

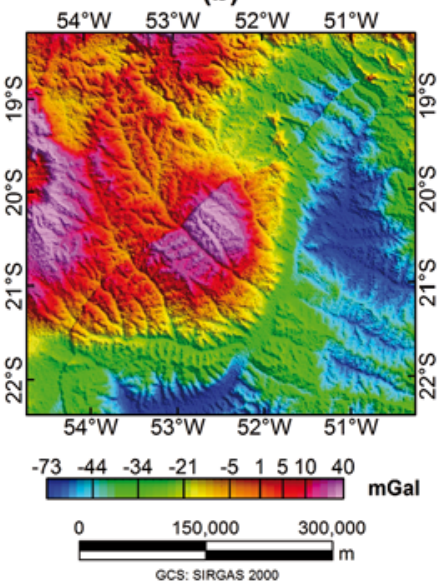

(c)

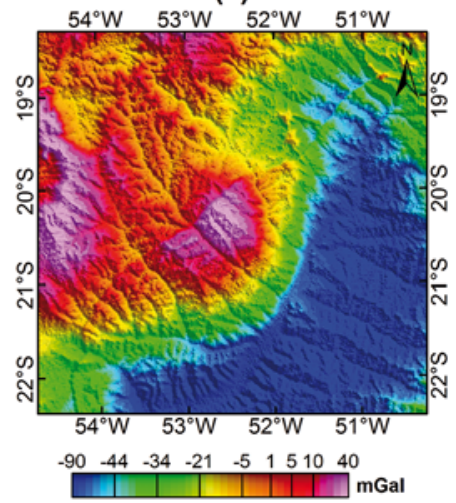

Figure 8 - Free-Air correction: (a) Real Data; (b) Model with constant density inside the Serra Geral Formation; (c) Model with variable density inside the Serra Geral Formation.

(a)

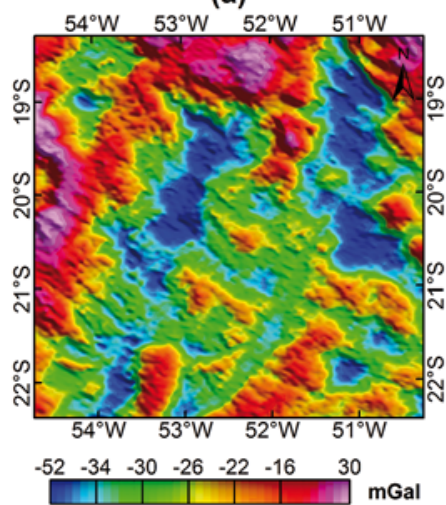

(b)

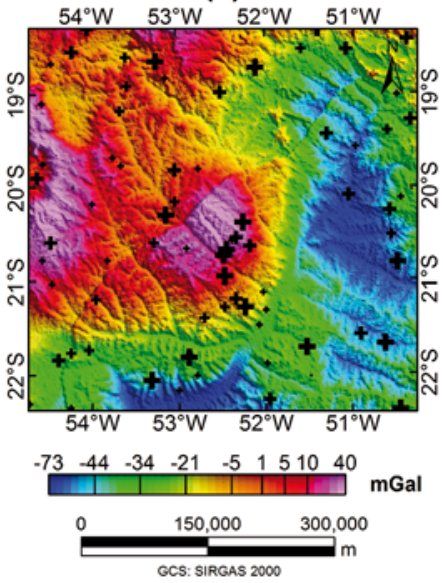

(c)

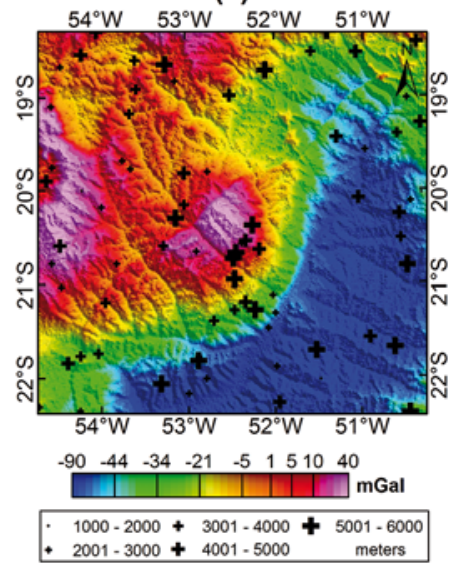

Figure 9 - Free-Air correction with the spatial location and depth of synthetic igneous bodies: (a) Real Data; (b) Model with constant density inside the Serra Geral Formation; (c) Model with variable density inside the Serra Geral Formation.

(a)

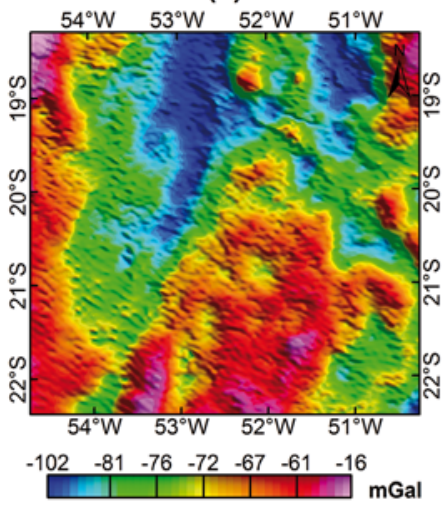

(b)

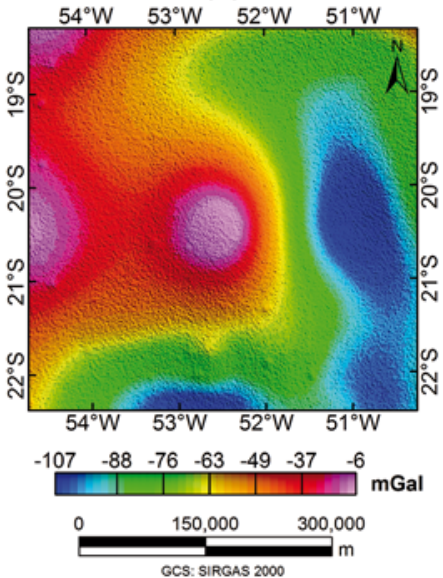

(c)

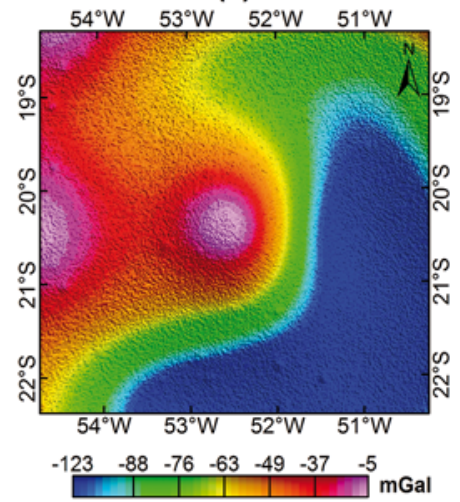

Figure 10 - Terrain Correction - (a) Real Data; (b) Model with constant density inside the Serra Geral Formation; (c) Model with variable density inside the Serra Geral Formation. 
(a)

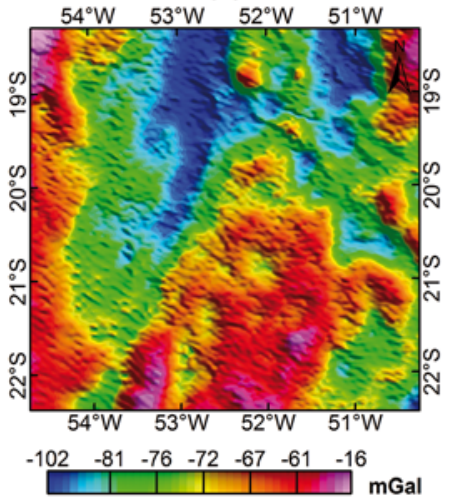

(b)

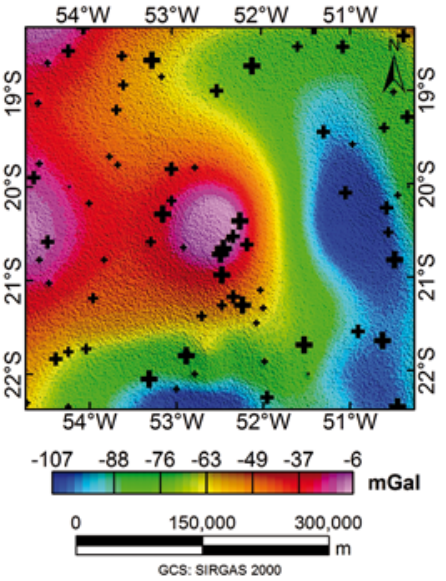

(c)

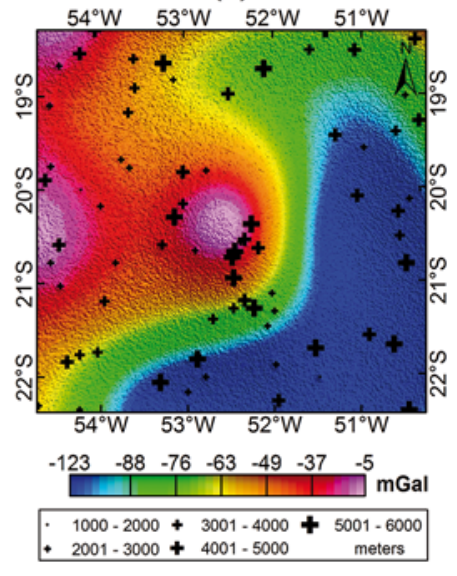

Figure 11 - Terrain Correction with the spatial location and depth of synthetic igneous bodies: (a) Real Data; (b) Model with constant density inside the Serra Geral Formation; (c) Model with variable density inside the Serra Geral Formation.

(a)

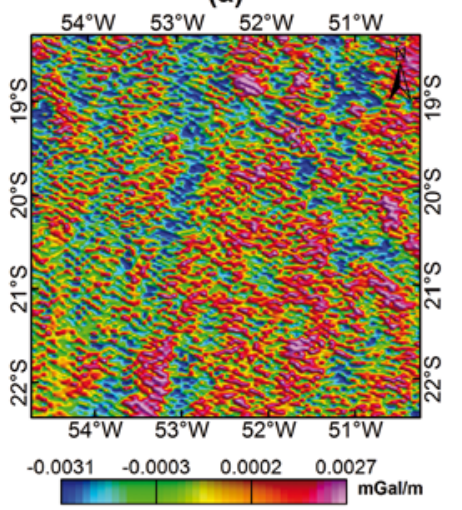

(b)

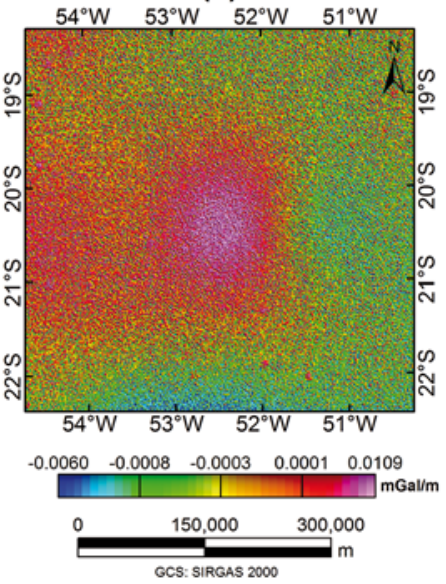

(c)

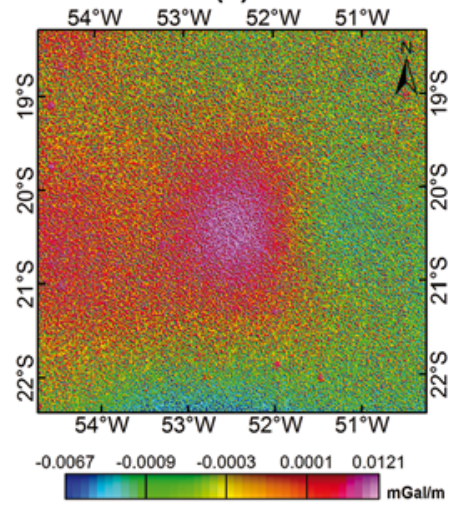

Figure 12 - Terrain Correction - First Derivative:(a) Real Data; (b) Model with constant density inside the Serra Geral Formation; (c) Model with variable density inside the Serra Geral Formation.

(a)

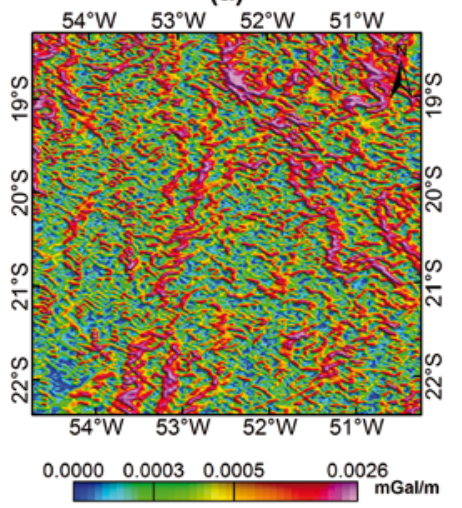

(b)

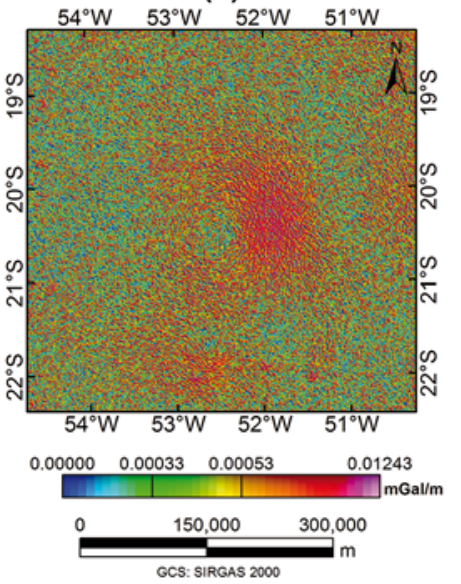

(c)

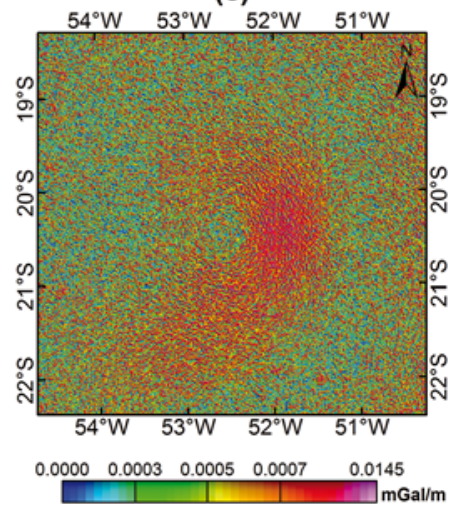

Figure 13 - Terrain Correction - Horizontal Gradient: (a) Real Data; (b) Model with constant density inside the Serra Geral Formation; (c) Model with variable density inside the Serra Geral Formation. 
(a)

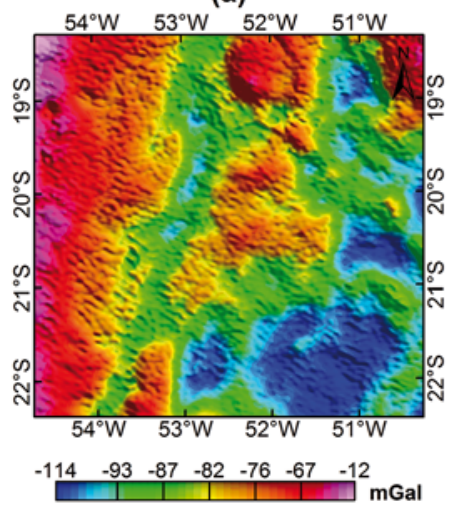

(b)

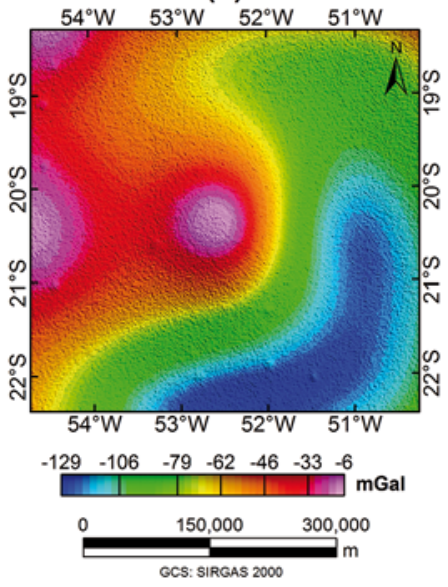

(c)

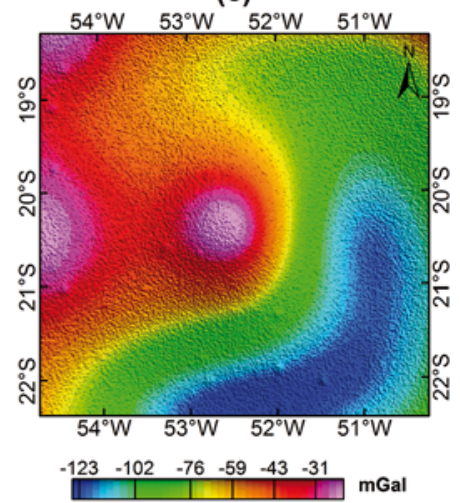

Figure 14 - Terrain correction and basalt gravity response removed (strip residual): (a) Real Data; (b) Model with constant density inside the Serra Geral Formation; (c) Model with variable density inside the Serra Geral Formation.

(a)

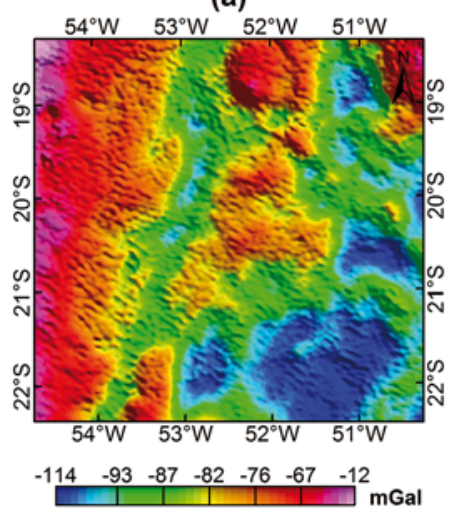

(b)

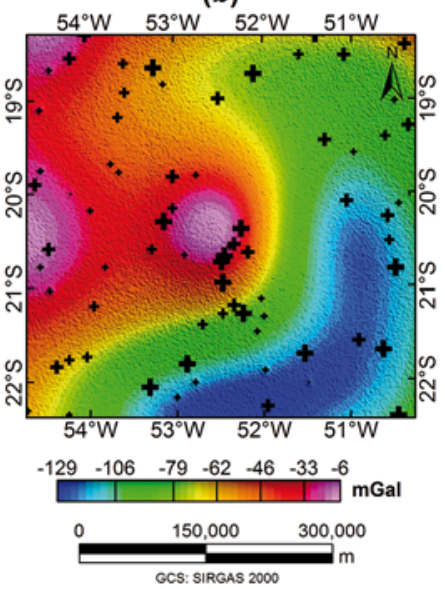

(c)

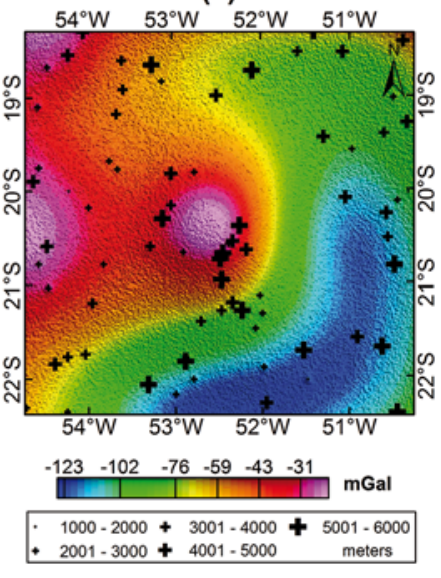

Figure 15 - Terrain correction and basalt gravity response removed (strip residual) with the spatial location and depth of synthetic igneous bodies: (a) Real Data; (b) Model with constant density inside the Serra Geral Formation; (c) Model with variable density inside the Serra Geral Formation.

(a)

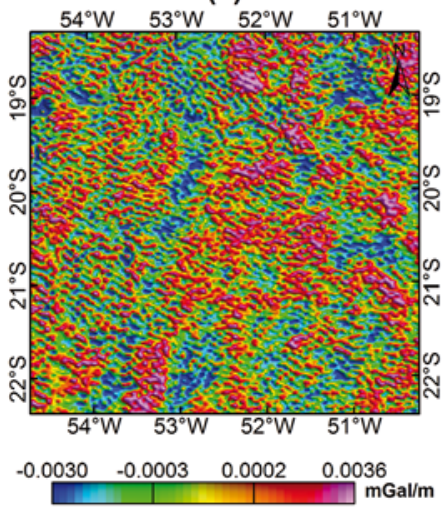

(b)

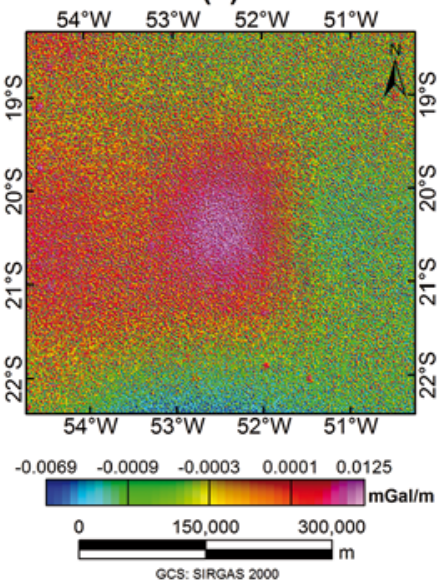

(c)

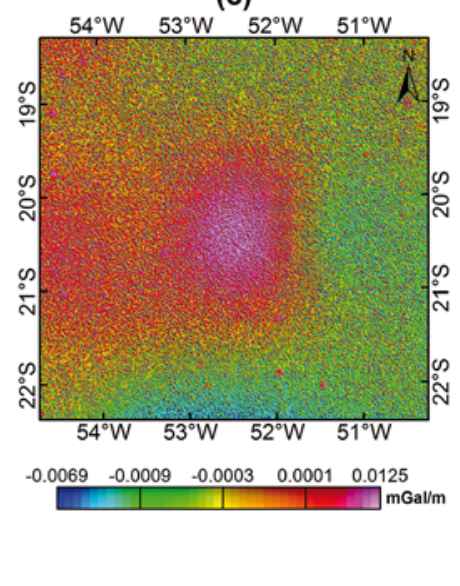

Figure 16 - Terrain correction and basalt gravity response removed (strip residual) - First Derivative: (a) Real Data; (b) Model with constant density inside the Serra Geral Formation; (c) Model with variable density inside the Serra Geral Formation. 
(a)

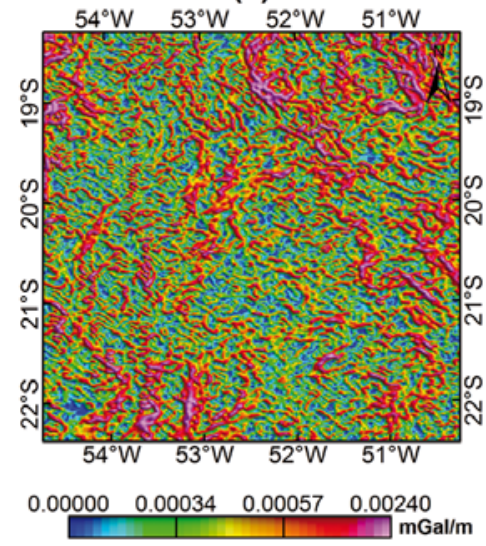

(b)

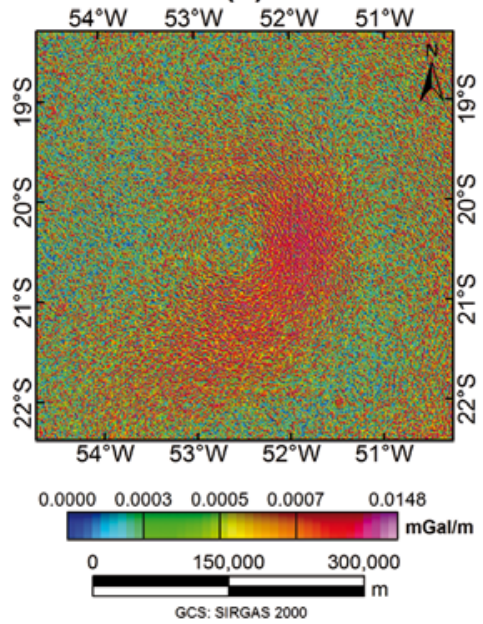

(c)

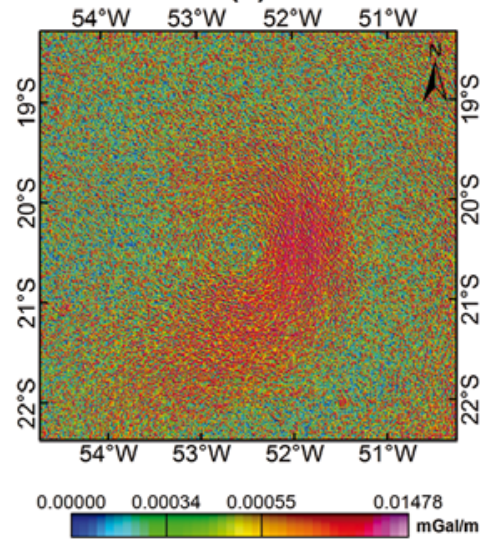

Figure 17 - Terrain correction and basalt gravity response removed (strip residual) - Horizontal Gradient: (a) Real Data; (b) Model with constant density inside the Serra Geral Formation; (c) Model with variable density inside the Serra Geral Formation.

(a)

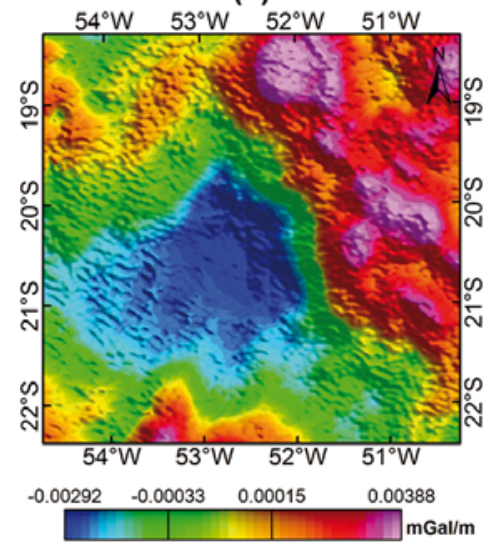

(b)

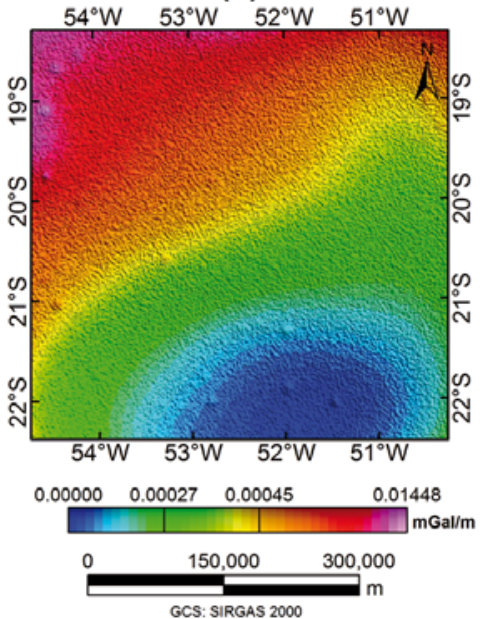

(c)

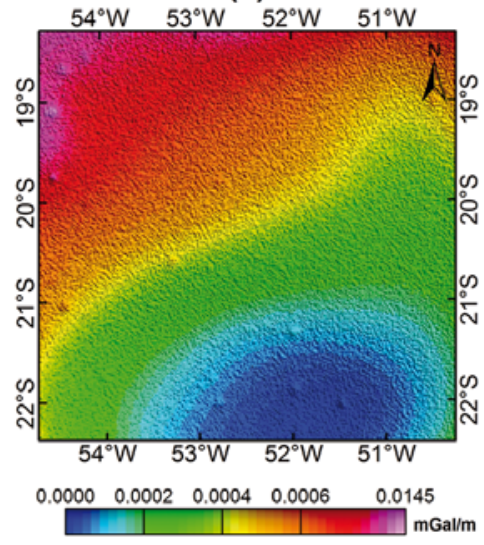

Figure 18 - Isostatic Correction: (a) Real Data; (b) Model with constant density inside the Serra Geral Formation; (c) Model with variable density inside the Serra Geral Formation.

however the results of the filtering, Figures 16(b) and 16(c) enhance new anomalies related to synthetic igneous bodies located in the extreme northeastern portion of the map. Figures 17(b) and 17(c) also enhances new anomalies related to synthetic igneous bodies in the southeastern portion of the maps. These results indicated that Serra Geral gravity model removal can improve the igneous bodies mapping. Finally, the results of the isostatic correction showed in the Figure 19, present a good overview of the anomalies related to synthetic igneous bodies, while the survey map (19a) changes completely the low frequency behavior of the data, not correlating with any interpreted gravity feature published about the basin (Quintas, 1995; Quintas et al., 1997). Figures 20 and 21 do not improve any feature compared with Figure 19.

\section{DISCUSSION}

Comparing the maps above described, the best combination to enhance the anomalies related to igneous intrusive rocks in the synthetic models is presented in the Figures 18(b) and 18(c): The Isostatic correction with no enhancements applied. Correspondently, the Figure 18(a) with the same analysis using the survey data, do not show correlated anomalies in terms of amplitude and frequency. The survey data maps produce small isolated anomalies in the Figures 17, 20 and 21, but, these anomalies probably represent the borders of regional low frequency anomalies. 
(a)

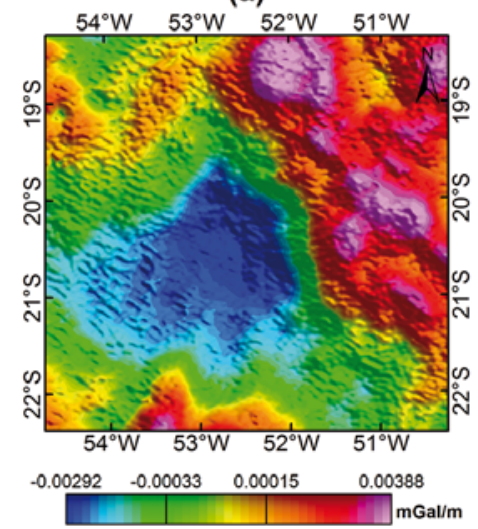

(b)

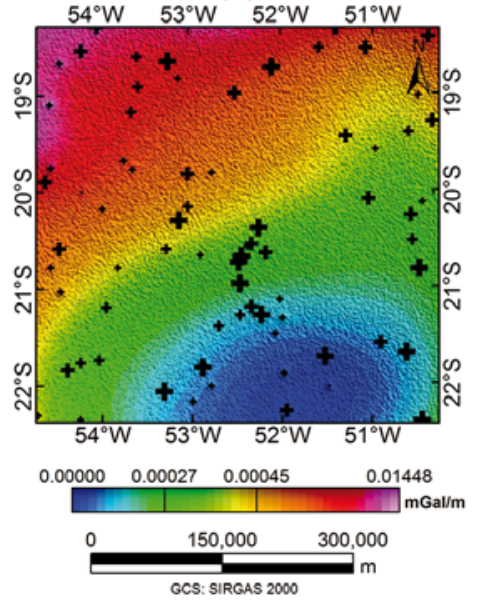

(c)

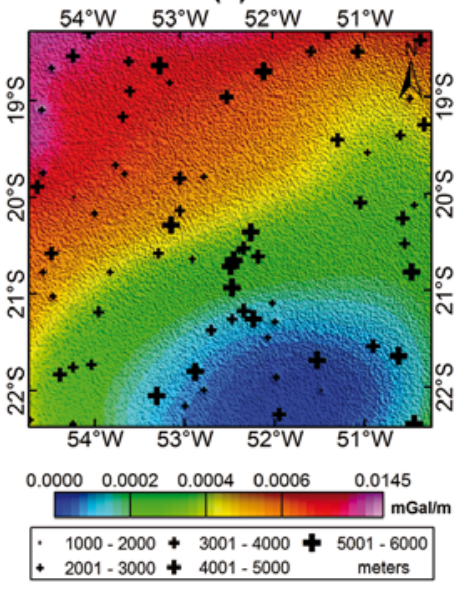

Figure 19 - Isostatic Correction with the spatial location and depth of synthetic igneous bodies: (a) Real Data; (b) Model with constant density inside the Serra Geral Formation; (c) Model with variable density inside the Serra Geral Formation.

(a)

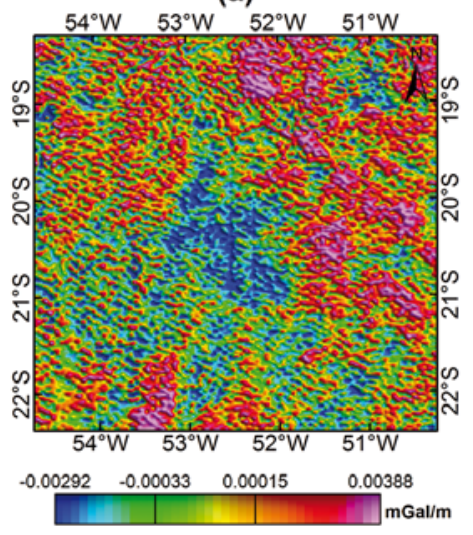

(b)

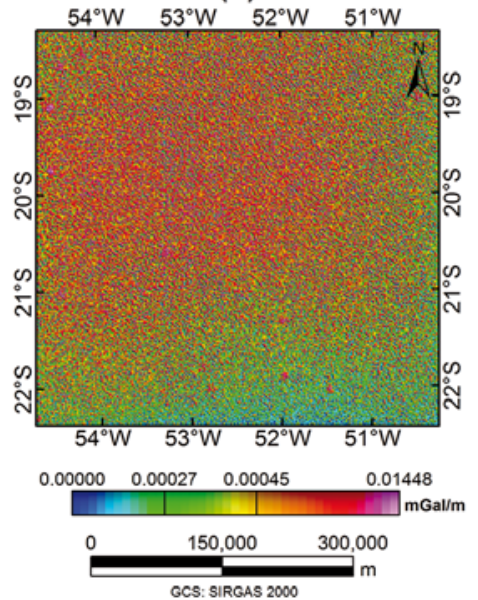

(c)

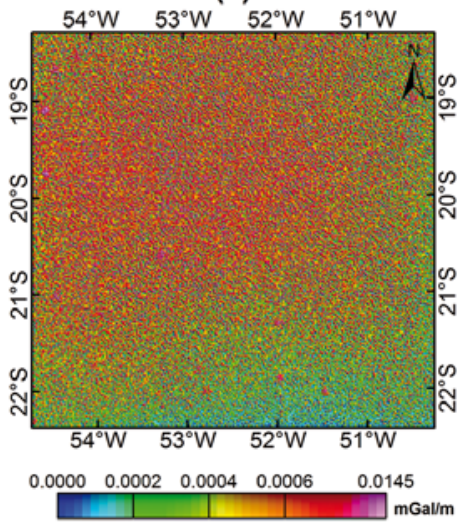

Figure 20 - Isostatic Correction - First Derivative: (a) Real Data; (b) Model with constant density inside the Serra Geral Formation; (c) Model with variable density inside the Serra Geral Formation.

We can see clearly the difference between Serra Geral constant density model and Serra Geral with variable density model in the Figures 8 and 10. Especially in the Figure 10(b), it is possible to see one small anomaly in the southern portion of the map that is not related with any synthetic igneous body. This difference suggests that density contrast inside Serra Geral can also impact in the imaging of the anomalies related to sub-basalt targets.

Surprisingly, the especial correction proposed to remove the complete gravity effect of the basalt model from the survey data, converted the low frequency positive anomaly present in the classical Bouguer with simple terrain correction (Figs. 4 and 10), in a regional low that also coincides with the basin depocenter (Quintas, 1995) and agrees with synthetic modeling (Fig. 14).
Aiming to evaluate if the basalt gravity response removal applied to real data can enhance the response of the underlying layers, we made a 2D model (Talwani et al., 1959) using a geoeletricdensity model proposed by Carreira (2015). The Figure 22 shows the location of the modeled profile and the result of the basalt gravity response removal applied to the whole area of the survey (strip residual). The density values used for this exercise were also acquired from this model (Fig. 23).

The idea was to evaluate the availability of modeling the same features present in the model proposed by Carreira (2015) (Fig. 23) using the strip residual (Fig. 22). If the gravity effect produced by a dense and shallow formation such as Serra Geral overtakes the effect from underlying and smaller features, after 
(a)

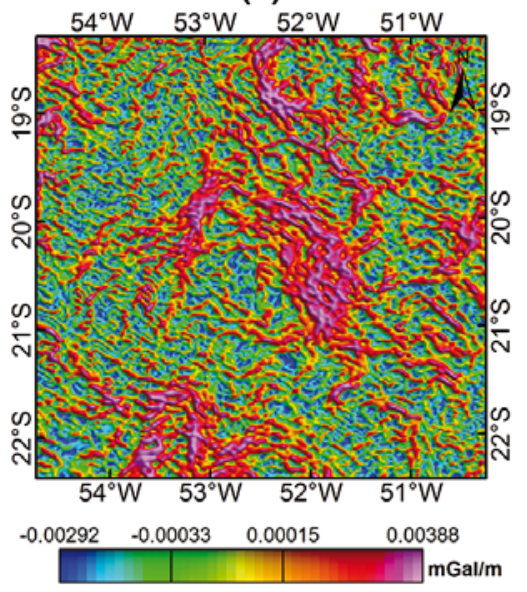

(b)

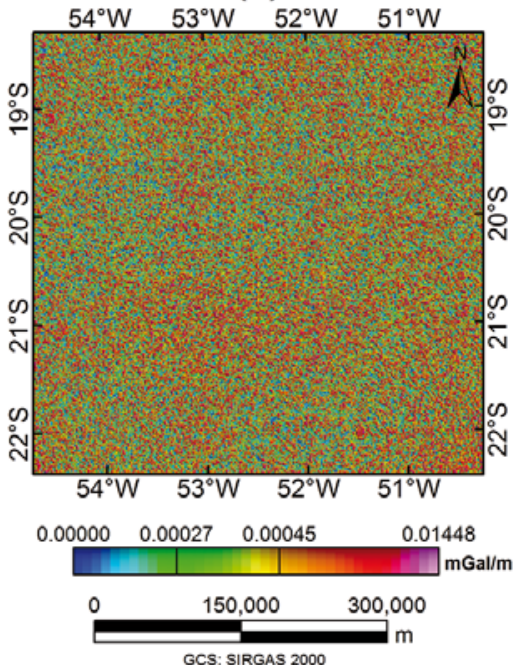

(c)

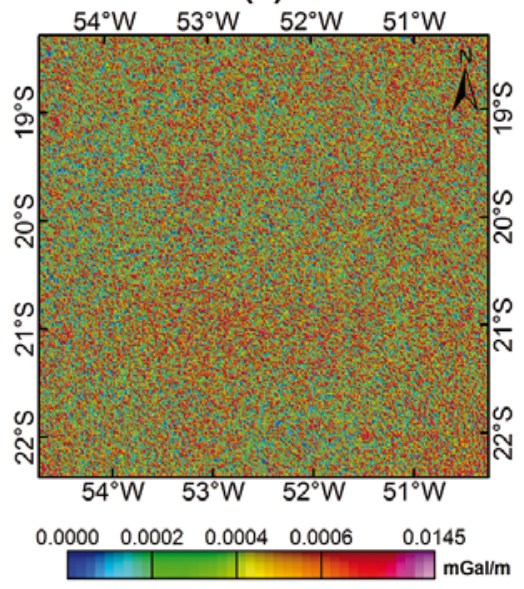

Figure 21 - Isostatic Correction - Horizontal Gradient: (a) Real Data; (b) Model with constant density inside the Serra Geral Formation; (c) Model with variable density inside the Serra Geral Formation.

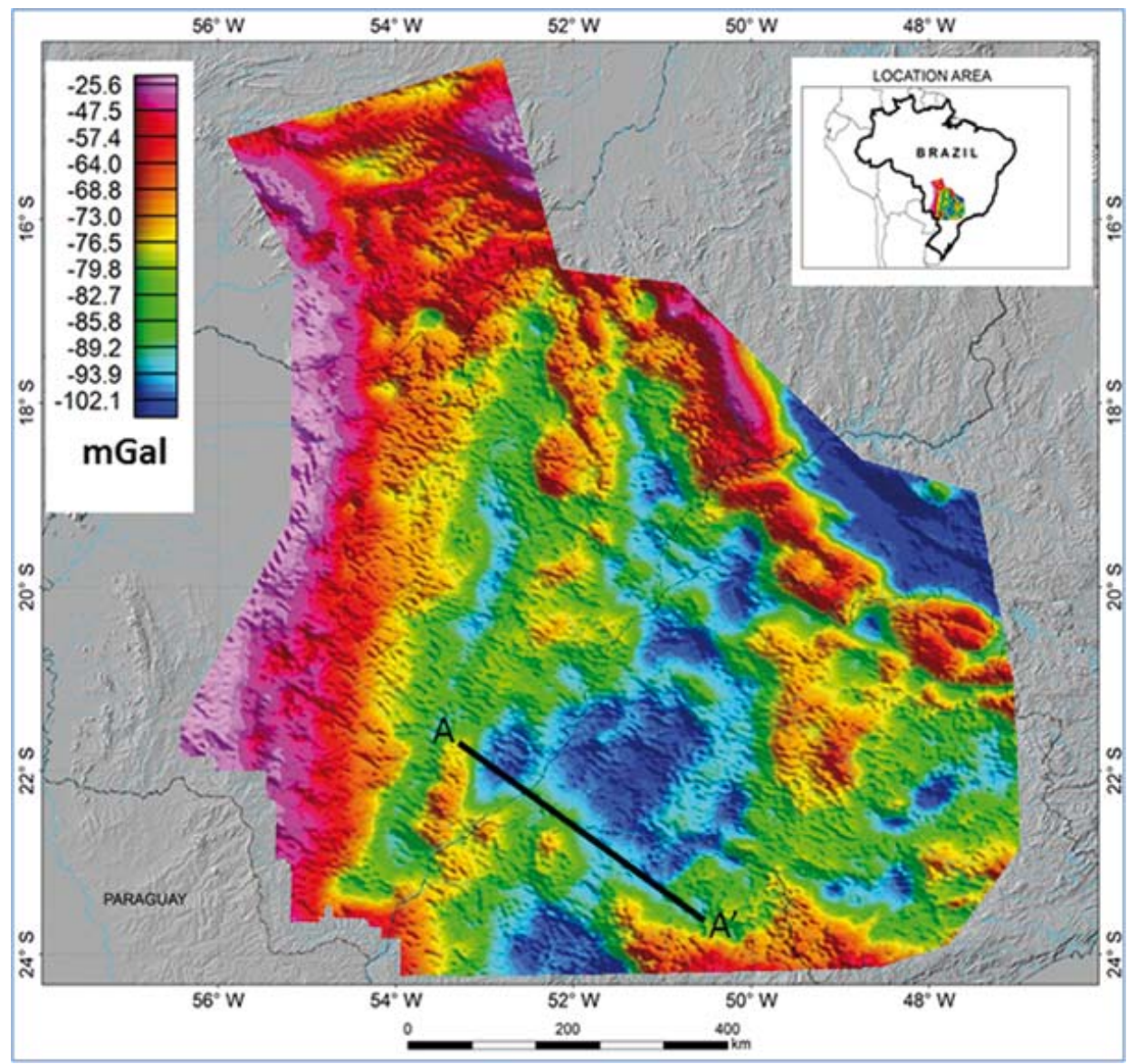

Figure 22 - Terrain correction and Serra Geral gravity response removal (strip residual) and Location map of the modeled profile. 


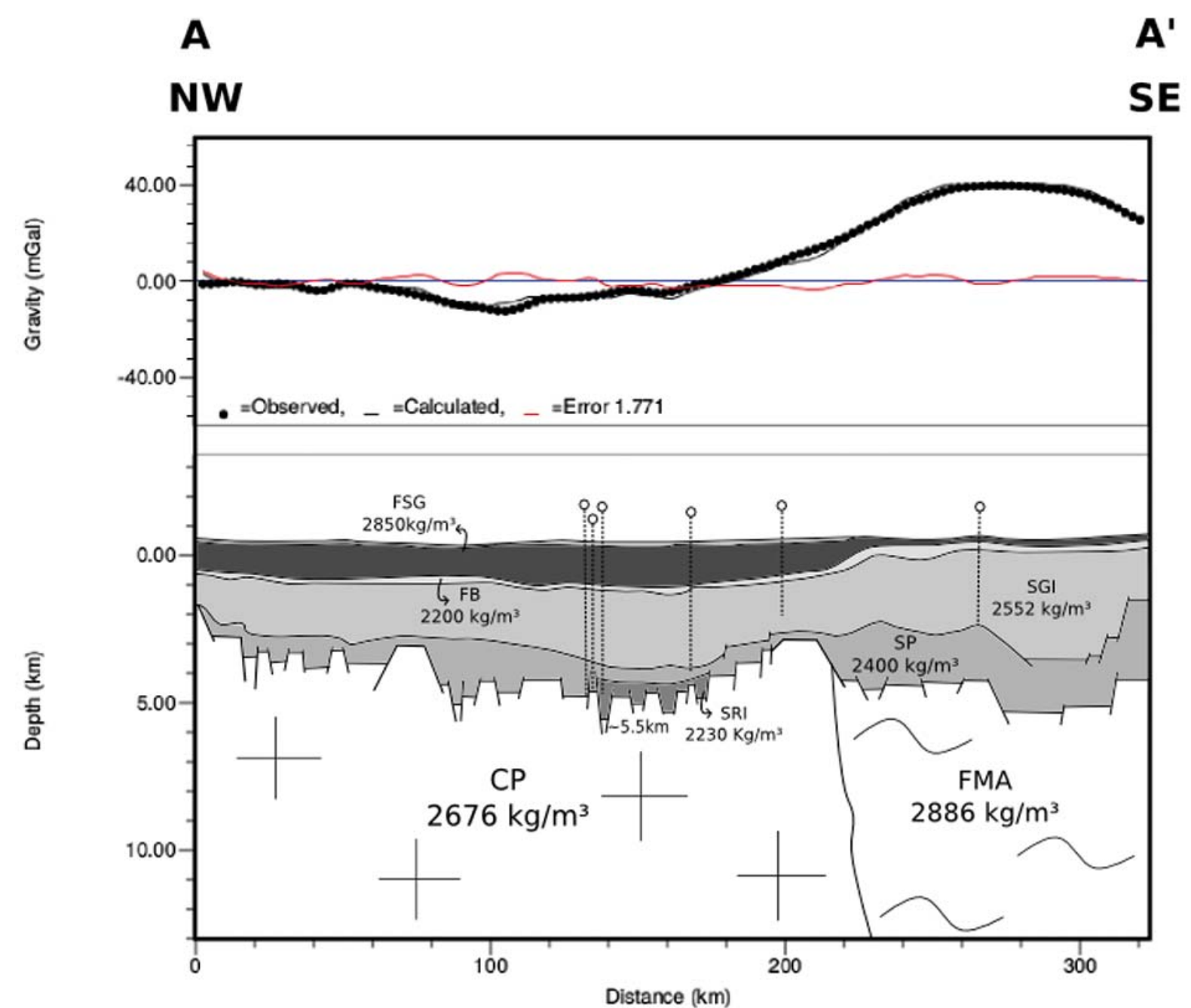

Figure 23 - 2D density section proposed by Carreira (2015) using Magneto Telluric/Gravity Bouguer Anomaly. The density blocks created to adjust the model are: GB (Bauru Group), GC (Cauia Group), FSG (Serra Geral Formation), FB (Botucatu Formation), SGI (Gondwana I Supersequence), SP (Paraná Supersequence), SRI (Rio Ivai Supersequence), CP (Paranapanema Craton), FMA (Apiai Fold Belt).

the removal, other anomalies and, consequently, geologic features may be proposed (Fig. 24). Using the same gravity values of the Carreira (2015), there is a misfit by a mass depletion. The proposed solution for this misfit is to input a dense body inside the pre-rift sequence in the center of the 2D model. This solution is compatible with the descriptions of Milani et al. (1994) related to the Três Lagoas magmatism in the Rio Ivaí supersequence during the late Ordovician $-460 \mathrm{Ma}-443 \mathrm{Ma}$. The density values applied to the $2 \mathrm{D}$ model consider terrain correction of $2.2 \times 10^{3} \mathrm{~kg} / \mathrm{m}^{3}$ besides the basalts gravity response removal with a contrast $0.65 \times 10^{3} \mathrm{~kg} / \mathrm{m}^{3}$, so the density values above geoid are zero and the Serra Geral Formation below geoid decreases $0.65 \times 10^{3} \mathrm{~kg} / \mathrm{m}^{3}$, remaining $2.2 \times 10^{3} \mathrm{~kg} / \mathrm{m}^{3}$. The other values applied are the same proposed by Carreira (2015).

\section{CONCLUSIONS}

The strip residual map (Fig. 22) without the gravity response of the basalt model shows clearly the shape of the basin and its axis. The axis of the basin is generally oriented at SW-NE, turning southwards at its southern end (Quintas et al., 1997). The plan shape of the basin seems to be much more irregular than previously thought. Even stripping the Serra Geral gravity response and in simplified models (forward models) it is very hard to map most of the synthetic igneous intrusive rocks. The real data here compared is a low-resolution data, with $6 \mathrm{~km}$ of line spacing and the high frequency content could not contain any systematic frequency content related to this features. High frequency segregation filters applied to real data seems not to enhance the 


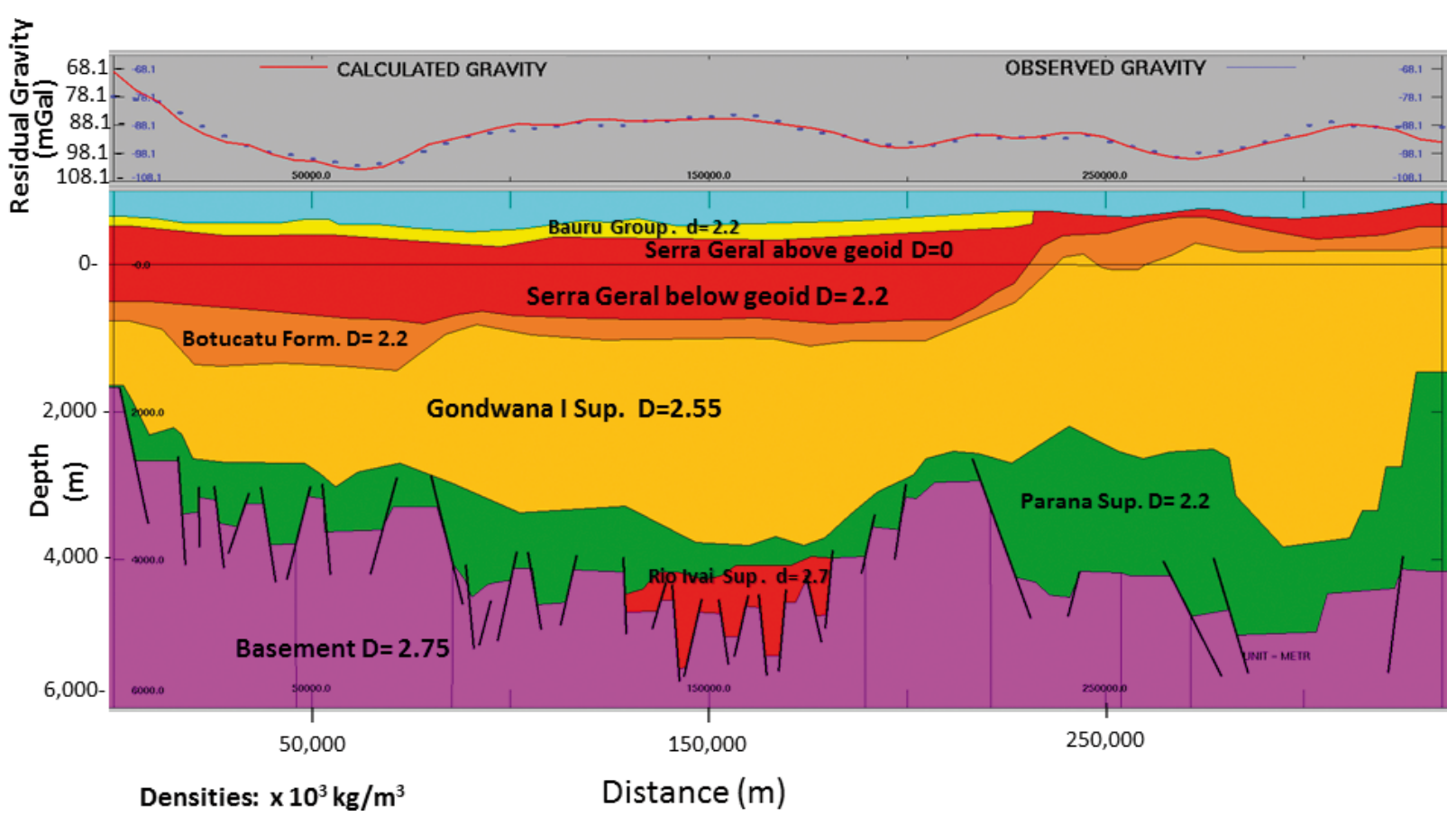

Figure 24 - 2D density section: Dense body inside the pre-rift sequence. - Terrain correction and Serra Geral gravity response removal (strip residual).

gravity response from intrusive rocks with the scale of the aimed targets, improving just the border of regional anomalies. It is also important to emphasize that noise content is amplified during the application of the derivative filters and difficult the mapping of the smaller and deeper intrusive rocks.

The isostatic correction using Crust 1.0 model did not address any interesting feature around the basin, instead; the correction changed completely the low-frequency anomaly structure of the study area. We do not see, in the survey data, any frequency content correlated to the strong low frequency gradient (high and low), located in the center of the area of study in the Crust 1.0 model (Fig. 5d).

These analyses support the idea that, without a consistent geometric-density model for the Serra Geral Formation, it will be hard to map geologic features in the scale of the Mato Rico and Barra Bonita fields underlying to Serra Geral Formation. By using electromagnetic methods combined with the strip residual data, it was possible to generate a residual gravity anomaly where we propose an igneous body in the Rio Ivaí Supersequence related to the Três Lagoas magmatism.

For future work, we suggest a strict focus in the Serra Geral Formation. High resolution surveys, with tight acquisition grid, should map lateral variations in density, and might support one improvement in the Serra Geral model, refining geometry and physical properties distribution, that represents the biggest challenge to develop a good surface density model and allow to image sub-basalt targets.

\section{REFERENCES}

ALMEIDA FFM de. 1980. Tectônica da Bacia do Paraná no Brasil. São Paulo, Instituto de Pesquisas Tecnológicas do Estado de São Paulo S/A. 187 pp. (IPT. Relatório, 14.091).

BLAKELY RJ. 1995. Potential theory in gravity and magnetic applications. Cambridge University Press, 441 pp.

BRYAN SE \& ERNST RE. 2008. Revised definition of Large Igneous Provinces (LIPS), Earth-Science Reviews, 86: 175-202.

CARDOSO RJ. 2015. Seminário Técnico-Ambiental da $13^{\mathrm{a}}$ Rodada de Licitações - Áreas com acumulações marginais - Bacias Potiguar, ES, Paraná e Barreirinhas, p. 70-90. Available on: <http://www.brasilrounds.gov.br/arquivos/Seminarios_R13AM/Seminario_Tecnico-ambiental-R13AM.zip > . Access on: December 10, 2016.

CARREIRA RV. 2015. Aplicação dos Métodos Gravimétrico e Magnetotelúrico na Contribuição do Entendimento das Estruturas Geológicas da Região Central da Bacia do Paraná, Centro-Sul do Brasil. Master Dissertation, Observatório Nacional, Rio de Janeiro, 93 pp.

CATTO AJ. 2008. Os exemplos dos Campos de gás de Barra Bonita e Mato Rico. Available on: www.anp.gov.br/SITE/acao/download/ ?id=4425. Access on: December 10, 2016. 
CORDANI UG, BRITO NEVESBB \& THOMAZ FILHO A. 2009. Estudo preliminar de integração do Pré-Cambriano com os eventos tectônicos das bacias sedimentares brasileiras (Atualização). Boletim de Geociências da Petrobras, 17: 205-219.

CPRM. Serviço Geológico do Brasil. 2004. Carta Geológica do Brasil ao Milionésimo, Brasília, Secr. Min. Metal., MME, Brazil, 41 CDs.

FARR TG, ROSEN PA, CARO E, CRIPPEN R, DUREN R \& HENSLEY S. 2007. The Shuttle Radar Topography Mission. Rev. Geophys., 45(2): RG2004, doi:10.1029/2005RG000183.

FRANK TH, GOMES MEB \& FORMOSO MLL. 2009. Review of the areal extent and the volume of the Serra Geral Formation, Paraná Basin, South America. Instituto de Geociências, Universidade Federal do Rio Grande do Sul, Porto Alegre, RS, Brazil, 36(1): 49-57.

GAMA JR E, BANDEIRA JR AN \& FRANÇA AB. 1982. Distribuição espacial e temporal das unidades litoestratigráficas paleozóicas na parte central da Bacia do Paraná. Revista Brasileira de Geociências, 12(4): $578-589$.

HASUI Y. 2010. A Grande Colisão Pré-cambriana do Sudeste Brasileiro e a Estruturação Regional, São Paulo, UNESP. Geociências, 29(2): 141-169.

HASUI Y, CARNEIRO CDR, ALMEIDA FFM \& BARTORELLI A. (Org.). 2012. Geologia do Brasil. São Paulo: Editora Beca, Brazil. v. 1. 900 pp.

LASKE G, MASTERS G, MA Z \& PASYANOS M. 2013. Update on Crust 1.0 - A 1-degree global model of Earth's crust. J. Geophys. Res., 15: 2658.

MARIANI P, BRAITENBERG C \& USSAMI N. 2013. Explaining the thick crust in Paraná Basin, Brazil, Satellite GOCE gravity data. Journal of South American Earth Sciences, 45: 209-223.

MILANI EJ. 1997. Evolução tectono-estratigráfica da bacia do Paraná e seu relacionamento com a geodinâmica fanerozóica do Gondwana suloriental. Doctorate Thesis, Universidade Federal do Rio Grande do Sul, Instituto de Geociências, Porto Alegre, Brazil, 255 pp.

MILANI EJ \& RAMOS VA. 1998. Orogenias paleozóicas no domínio sulocidental do Gondwana e os ciclos de subsidência da Bacia do Paraná. Revista Brasileira de Geociências, 28(4): 527-544.

MILANI EJ, FRANÇA AB \& SCHNEIDER RL. 1994. Bacia do Paraná. Boletim de Geociências da Petrobras, 8(1): 69-82.
MILANI EJ, FRANÇA AB \& MEDEIROS RA. 2007. Rochas geradoras e rochas-reservatório da Bacia do Paraná, faixa oriental de afloramentos, Estado do Paraná. Boletim de Geociências da Petrobras, Rio de Janeiro, 15(1): 135-162

PICCIRILLO EM \& MELFI AJ (Eds.). 1988. The Mesozoic Flood Volcanism of the Paraná Basin: Petrogenic and Geophysical Aspects. Instituto Astronômico e Geofísico, Universidade de São Paulo, São Paulo, Brazil, $600 \mathrm{pp}$.

PICCIRILLO E, COMIN-CHIARAMONTI P, MELFI A, STOLFA D, BELUENI G, MARQUES L, NARDY A, PINESE J, RAPOSO M \& ROISENBERG A. 1987. Petrochemical of continental flood basalt-rhyolite suites and related intrusives from the Paraná Basin (Brazil). The Mesozoic flood volcanism from the Paraná Basin: Petrogenetic and Geophysical Aspects. São Paulo, IAG, Brazil, 107-156.

QUINTAS MCL. 1995. 0 Embasamento da Bacia do Paraná: Reconstrução geofísica de seu arcabouço. São Paulo, Doctorate Thesis, IAG-USP, Brazil. 213 pp.

QUINTAS MCL, MANTOVANI MSM \& ZALÁN PV. 1997. Contribuição ao Estudo da Evolução Mecânica da Bacia do Paraná. Boletim de Geociências da Petrobras, Rio de Janeiro, 11: 48-73.

REIS S, MIZUSAKI M, ROISENBERG A \& RUBERT R. 2014. Formação Serra Geral (Cretáceo da Bacia do Paraná): um análogo para os reservatórios ígneo-básicos da margem continental brasileira. Pesquisas em Geociências, 41(2): 155-168.

SANDWELLD, GARCIA E, SOOFIK, WESSEL P, CHANDLER M \& SMITH WHF. 2013. Toward 1-mGal accuracy in global marine gravity from CryoSat-2, Envisat, and Jason-1. The Leading Edge, 32(8): 892-899.

TALWANI M, WORZEL JL \& LANDISMAN M. 1959. Rapid gravity computations for two-dimensional bodies with application to the Mendocino submarine fracture zone. J. Geophys. Res., 64(1): 49-59.

UIEDA L, OLIVEIRA JR VC \& BARBOSA VCF. 2013. Modeling the Earth with Fatiando a Terra. In: Proceedings of the 12th Python in Science Conference, pp. 91-98.

ZALÁN PV, WOLFS, CONCEIÇÃO JC DE J, MARQUES A, ASTOLFI MAM, VIEIRA IS, APPI VT \& ZANOTTO OA. 1990. Bacia do Paraná. In: RAJA GABAGLIA GP \& MILANI EJ. (Eds.). Origem e evolução de bacias sedimentares. Rio de Janeiro: Petrobras. 1990. pp. 135-168. 